\title{
Alkoholio žalos suvokimo įtaka blaivybės judėjimams palaikyti XIX a. ir XX a. pradžioje
}

\author{
Ilona Tamutienè \\ Vytauto Didžiojo universitetas \\ K. Donelaičio str. 58, 44248, Kaunas, Lietuva

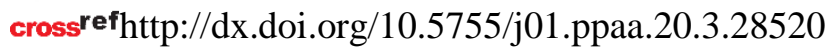

\begin{abstract}
Anotacija. Šio straipsnio tikslas - atskleisti alkoholio žalos vaidmens suvokima blaivybès judëjimu (BJ) ir juos rèmusiu skirtingu interesu grupiu viešosios politikos siekiniuose. Tikslui pasiekti keliami uždaviniai: 1) aprašyti alkoholio politikos interesus; 2) atskleisti, kaip alkoholio žala buvo suvokiama klasikinio liberalizmo kontekste; 3) identifikuoti, kaip alkoholio žala pozicionavo BJ; 4) išskirti BJ palaikiusias interesu grupes bei politini atsaka i socialiniu grupiu reikalavima. Straipsnis remiasi literatūros apžvalga bei interpretacija. Blaivybès hegemonijos (XIX a. ir XX a. pr.) laikotarpiu socialiniai judèjimai ir skirtingos interesu grupès alkoholio žala suvokè holistiškai: pradedant geriančiuoju, bet pabrėžiant bendruomenès interesa. Klasikinis liberalizmas alkoholio žala kitiems nei geriantysis laikè pagrịstu principu riboti geriančiojo laisvę. Atsižvelgiant $i$ moralini reguliavima, blaivybe buvo dorybè ir aukštesnio statuso tapatybès bruožas, siejamas su asmens orumu, verte, produktyvumu, sveiku ir išsilavinusiu (ar to siekiančio) piliečiu. Socialiniai judèjimai, propagavę ir palaikę blaivybę, leido žmogui rinktis tarp dviejų kraštutiniu alternatyvu, iš kuriu viena vede i degradacija, kita - i klestejima. Šalia BJ, kuriu nariai duodavo priesaika nevartoti alkoholio, neskatinti kitu ir propaguoti blaivybę, buvo daug juos palaikiusiu interesu grupiu: moterys, kurios siekè šeimos ir šalies gerovès bei savo teisiu; darbininkai, kurie sieke savo teisiu; kapitalistai, kuriems reikejo blaiviu darbuotoju; socialistai, kuriems reikejo darbininku balsu; bolševikai, kuriems reikejo blaiviu darbininku proletarinei sąmonei ugdyti. Blaivybe buvo išsilaisvinimo iš vergijos ir baudžiavos, tautinès sąmonès ugdymo, suverenios valstybès kürimo priemonè, skatinusi išsilavinima ir sveikata. Blaivybe palaike eugenikos, higienizmo, rasès gryninimo judejjimai. Per individualu ir kolektyvini veiksma BL blaivu gyvenima ipprasmino kaip aukštesniu tiksly siekimo priemonę. Siekiant blaivybei tinkamos aplinkos, reikejjo griežtos alkoholio politikos: nuo griežto licencijavimo iki visiškos prohibicijos.
\end{abstract}

Raktažodžiai: blaivybès judèjimai, alkoholio žala, interesu grupès, alkoholio politika Keywords: temperance movements, alcohol's harm, interest groups, alcohol policy

\section{Ivadas}

Alkoholio žalos kitiems nei pats geriantysis klausimai nuo II pasaulinio karo buvo ignoruoti iki antrojo tūkstantmečio pabaigos. Śiuo laikotarpiu alkoholio politika buvo sutelkta ị priklausomybių gydymą bei alkoholio fiskalinị ir ekonomini interesus (Room et al, 2010). Pastaruoju dešimtmečiu kyla alkoholio žalos kitiems nei geriantysis tyrimų banga (Laslett, Callinan, Pennay, 2013), alkoholio žalos mažinimo klausimo integravimas i globalius tvaraus vystymosi tikslus (Flor, Gakidou, 2020) rodo alkoholio politikos posūkị nuo ekonominio intereso link visuomenès sveikatos (Örnberg, 2008).

Tyrinėjant alkoholio žalą kitiems nei geriantysis, kyla pagrịstas klausimas, kodèl atkūrus Lietuvos nepriklausomybę jau tris dešimtmečius alkoholio politikos interesai yra siejami tik su žala geriančiojo sveikatai bei šalies ūkiui (Tamutienė, Graužinè, 2013). Teigini, kad alkoholis yra ịprasta preke, kuriai nereikia specialių apribojimų, $2015 \mathrm{~m}$. palaikè trečdalis Europos gyventojų, o kad nuo alkoholio keliamos žalos jie gali apsisaugoti patys be valstybės pagalbos net du trečdaliai (Moskalewicz, Room \& Thom, 2016, 222-223 p.). XXI a. pirmosios pusės požiūris ị alkoholị labai 
nutolęs nuo XIX a.-XX a. pradžios suvokimo, kai alkoholis buvo traktuojamas kaip nuodas, kuri reikia uždrausti (Levine, 1984).

Ieškant atsakymų, kodèl alkoholio žala kitiems nei pats geriantysis yra toleruojama, vis daugiau mokslininkų krypsta į blaivybès hegemonijos periodą, datuojamą XIX a.-XX a. pr. (Lucas, 2004; Roberts, 2019; Lee et al, 2020) ir piką pasiekusi prohibicijos įvedimu pirmiausiai Rusijos imperijoje (Herlihy, 2017), o vèliau ir JAV (Room, 2004). Šiandien sunku net įsivaizduoti valstybèje priimamą politini sprendimą, kuris atsisakytų su alkoholiu susijusių valstybès fiskalinio ir ekonominio interesų ir įvestų prohibiciją, tačiau XIX a. ir XX a. pr. kontekstas buvo kitoks.

Šio straipsnio tikslas yra atskleisti alkoholio žalos vaidmens suvokimą blaivybès judèjimų (BJ) ir juos rèmusių skirtingų interesų grupių viešosios politikos siekiniuose.

Tikslui pasiekti keliami šie uždaviniai: 1) aprašyti alkoholio politikos interesus; 2) atskleisti, kaip alkoholio žala buvo suvokiama klasikinio liberalizmo kontekste; 3) identifikuoti, kaip alkoholio žalą pozicionavo BJ; 4) išskirti blaivybės judèjimus palaikiusias interesų grupes bei politini atsaką i socialinių grupių reikalavimą.

Straipsnis remiasi naratyvine literatūros apžvalga bei interpretacija (Ferrari, 2015; Collins, Fauser, 2005). Duomenys analizei rinkti elektroninèse duomenų bazèse (Google Scholar, EBSCO), o internetu neprieinamų šaltinių ieškota bibliotekose. Analizuota literatūra, kuri susijusi su BJ procesais, alkoholio žalos mažinimo politika XIX a. ir XX a. pradžioje. Tikslui realizuoti derintos socialiniu judejimu ir viešosios politikos réminimo teorinès prieigos (Sandberg, 2006). Viešosios politikos rèminimo prieiga leidžia atskleisti alkoholio problemą iš skirtingų veikèjų ir skirtingų valstybės interesų derinimo perspektyvos. BJ alkoholio problemos rèminimo centre kèlè alkoholio žalos individui, šeimai ir visuomenei klausimą, pateikdami sprendimus, ịskaitant politinius (Room, 2004; Sulkunen, 1987). Nors BJ buvo atsakas ị laissez-faire politiką, tačiau jų idejos derèjo su J. St. Millis'o (1995) klasikinio liberalizmo nuostatomis, pateisinančiomis valstybès kišimąsi žalos principu. BJ veikla atskleidžiama naujų socialiniu judejjimu teorijos, kilusios XIX a., rèmuose (toliau - NSJ). NSJ teorija peržengia oficialių institucinių kanalų ribas ir charakterizuoja socialinius judèjimus kaip siekiančius tam tikro gyvenimo būdo, etikos, tapatybės, o ne vien siaurų ekonominių tikslų. Šie judejjimai apibūdinami kaip „nauja politinè veikla“, susijusi su gyvenimo būdu, individo savirealizacija ir žmogaus teisèmis. Nors NSJ teorija „senus“ judéjimus apibūdina kaip socialinių klasių, siekiančius visas socialines bėdas išspręsti per politinị ir ekonominị pertvarkymą, tačiau BJ analizė papildo Calhoun'o (1994) įžvalgas apie NSJ pliuralistinį, sudètingą kontekstą ir ištakas, glūdinčias XIX a.

Yeomens'as (2011) argumentavo britų įtaką BJ politikai ir platesnei visuomenès raidai, atskleisdamas, kad per moralinio reguliavimo perspektyvą judejjimai paveikè individualius elgesio sprendimus, ịskaitant ir alkoholio licencijavimą. Britų BJ turẻjo reikšmingą ilgalaiki poveikị teisinėms, euristinėms ir moralinėms sistemoms, kurios veikia ir šiuolaikinę alkoholio klausimo sritį. Alkoholio politikos tyrimai atskleidè, kad skandinavų alkoholio monopolio ir britų ir licencijavimo sistema yra šiuolaikinès alkoholio politikos modelis, kuri taikè JAV, nutraukdama prohibiciją (Levine, Reinarman, 1991), bei kitos šalys, įskaitant ir Lietuvą (Room, 2004; Tamutienè, Andrejeva \& Lazauskienè, 2016).

\section{Alkoholio politikos interesai}

Alkoholio klausimai apima valstybès interesus, susijusius su fiskalinès, ekonominès, viešosios tvarkos ir saugumo, sveikatos, gerovès ir reprodukcijos sričių atsakomybėmis. Fiskalinis ir ekonominis interesai dažniausiai teigiamai susiję su alkoholinių gėrimų gamyba bei pardavimais, o kartu ir alkoholio vartojimo augimu, tačiau didesnis alkoholinių gėrimų vartojimas visuomenèje valstybės tikrajam interesui (ekonominio augimo ir socialinių teisių užtikrinimo kiekvienam piliečiui) yra dviprasmis. Pavyzdžiui, per didelè girtuoklystė šalyje mažina indèli i ekonomiką ir didina nusikalstamumą. Valstybès viešosios tvarkos, sveikatos ir reprodukcijos interesai dažniausiai susiejami su mažesniais alkoholio pardavimais ir vartojimu, nes kuo mažiau suvartojama alkoholio, tuo mažiau su viešaja tvarka, saugumu ir reprodukcija susijusių problemų yra šalyje (Mäkelä ir 
Viikari, 1977; Room, 1999). Žvelgiant ị viešosios politikos formavimo procesus, alkoholio politikos interesai, atstovaujami skirtingomis logikomis besivadovaujančių veikèjų, atspindi skirtingas problemas.

Šiandien sunku įsivaizduoti politikus, teikiančius prioritetą geriančiųjų aplinkinių sveikatos, saugumo ir reprodukcijos interesus, kaip tai vyko prohibicijos laikais, kai fiskalinis ir ekonominis alkoholio interesai buvo aukojami dẻl aukštesnių tikslų. Distiliavimas, pasterizacija, šaldymas ir pakavimas leido globaliai prekiauti ịvairiais greitai negendančiais alkoholio produktais, kuriuos buvo galima transportuoti i tolimas rinkas (Fogarty, 1985; Room, 1997). Taip alkoholinių gėrimų gamyba tapo vis labiau industrializuota ne tik išsivysčiusiose šalyse, bet ir visame pasaulyje, įskaitant Lietuvą, kur alaus daryklos pradètos steigti nuo XVII a. pabaigos (Lietuvos alkoholinès bendrovès). Rusijos Imperijos biudžetas, vadintas ,girtu biudžetu“, iš alkoholio surinkdavo apie trečdali savo pajamų, tačiau Rusijos Imperija ịvede prohibiciją anksčiau nei JAV (Herlihy, 2003, 138 p.). Remiantis tik ekonominiu interesu, prohibicija atrodytų visiškai nelogiškas žingsnis, juolab kad pinigu poreikis, susijęs su Pirmuoju pasauliniu karu, revoliucijomis, buvo labai didelis. Galima daryti prielaidą, kad alkoholio žalos suvokimas bei alkoholio problemos rėminimas ir politinis atsakas ị problemą XIX a. ir XX a. pradžioje skyrèsi nuo XX a. viduryje įsigaliojusio suvokimo, tarptautiniu lygmeniu pateikiamo pagal laisvosios prekybos ir vartotojų suvereniteto doktrinas (Room, 1997).

\section{Piktnaudžiavimo alkoholiu žalos klausimas liberalizmo kontekste}

Iki XIX a. stiprus alkoholis, kai kuriose šalyse vadintas gyvybès vandeniu, vartojamas nesaikingai ir kai apima vis platesnę visuomenès dali, tampa mirties vandeniu (Cockx, Meloni \& Swinnen, 2019). Žalingo alkoholio poveikio suvokimas skatina kurtis BJ pirmiausia Amerikoje, o po to Europoje, įskaitant ir Lietuvą (Kačerauskas, 2013). BJ itin susiję su klasikine liberalia mintimi. Viena vertus, BJ galima traktuoti kaip atsaką i laisez-faire politiką ir jos sukeltas problemas. Antra vertus, BJ apeliavo ị pagrindinị valstybès tikslą, kuris pagal klasikinị liberalizmą yra apsaugoti žmogaus teises ị gyvybę, laisvę, nuosavybę ir laimès siekimą. Klasikinis liberalizmas smurto ir žalos suvaržymo atsakomybę patiki valstybei vardan teisių ir lygybès apsaugos (Butler, 2015). Dauguma XIX amžiaus klasikinių liberalų ekonomistų pritare ịvairiai valstybės politikai, apimančiai ne tik baudžiamaji įstatymą ir sutarčių vykdymą, bet ir specialistų licencijavimą, sveikatos, saugos ir priešgaisrines taisykles, bankų taisykles, komercinę infrastruktūrą (kelius, uostus ir kanalus) ir kitų sričių, susijusių su žala, reguliavimą (Gaus, 1983). Galiausiai neblaivumas nederèjo su liberalios laisvès suvokimu.

Liberalusis laisvès suvokimas - galimybè rinktis, veikti ir galvoti patiems be kontrolès ar apribojimų, skatino kurtis ir veikti įvairias socialines grupes, turinčias savo interesų. Tai buvo taikoma asmeninio elgesio, socialinès sąveikos ir politinių veiksmų sferoms (Coombs, 2011). Galimybė rinktis buvo itin akcentuojama. Tam pasitarnavo požiūrio ị blaivybę ir girtavimą moralinis modelis. Blaivybės spauda girtumą visada vertino kaip nuodėmę ir ligą (Porter, 1985). Alternatyva buvo dorybè, sveikata, kurią galima gauti per blaivų gyvenimo būdą. Todẻl blaivybès skleidimas vyko operuojant sąvokomis, kurios buvo nukreiptos i individo elgesio keitimą. Centrinè diskurso sąvoka buvo (ir lieka) savikontrolé. Savikontrolè buvo suvokiama kaip pagrindinè moralinė, socialinè, psichologinè problema, tiek individo, tiek visuomenès lygiu (Levine, 1992; Sulkunen, \& Warpenius, 2000). Kvietimas keisti save iš nuodėmingo i dorą, iš girtuoklio i blaivininką ar iš paniekinto ì gerbtiną buvo galingas motyvuojantis užtaisas, kuris stiprino siekti aukštesnių nei vien individualių tikslų. Skirtingas kokybines būsenas apibrěžiančios sąvokos, tokios kaip blaivybe் vs girtumas, dorybè vs nuodème, savitvarda vs nesitvardymas, pagarba vs panieka, valios jèga vs priklausomybe buvo naudojamos motyvuoti žmones geresniam gyvenimui, kolektyviniam gèriui, šalies ateičiai. Diskurso retorika paremta dviejų alternatyvų sulyginimu, atskleidžiant neigiamas pasekmes ir skatinant teigiamas atsakomybes, pabrėžiant individo dalyvavimo savo ir kolektyvo gyvenime. Minètos sąvokos padèjo sukurti hegemoniją, padẻjusią išsaugoti socialinę tvarką besikeičiančioje, sparčiai modernèjančioje visuomenèje. 
Atrodytų sunkiai įtikinama, kad alkoholio kontrolė galèjo derèti su liberalizmo ideologija. Tačiau šią dilemą sprendè aiškiai ịvardijamas žalos kitiems principas. Siekiant suderinti laisvès ir gerovès interesus žalos kitiems principas buvo priimtinas tiek priespaudą kentusioms socialinėms grupėms (pavyzdžiui, moterims, vergams, darbininkams, juodaodžiams), tiek bažnyčiai, tiek politikams. Tarptautiniu lygiu visuomenes vienijo bendras vardiklis: girtumas buvo matomas kaip visų problemų šaltinis ir grèsmè saugumui. Šị požiūrị apibūdina tipinė citata: „,kiekvienas neblaivumas yra arba potencialus nusikaltimas, našta viešiesiems finansams, pavojus geriančiajam arba jo aplinkiniams, arba priežastis nelaimei, terorui, skandalui, triukšmui šeimai ar kitiems su neblaiviu asmenius susietiems asmenims“ (Edman, 2015, 23 p. cit. Branthwaite, 1909).

Esè „Apie laisvę“ J. St. Mill’is rašo:

„,vienintelis individualiu arba kolektyviniu požiūriu pateisinamas žmonijos tikslas kišantis ị bet kurio kito jos nario ar narių veikimo laisvę yra savisauga. Vienintelis tikslas, kuriuo teisètai galima panaudoti jègą prieš bet kurị civilizuotos bendruomenès narį, jam nesutinkant, yra neleisti padaryti žalos kitiems. Fizinis ar moralinis jo paties gèris nėra pakankamas pateisinimas. Vienintele žmogaus elgesio dalis, už kurią jis atsakingas visuomenei, yra toji dalis, kuri liečia kitus. Dél elgesio dalies, kuri liečia tik jị patį, jo nepriklausomybè teisètai yra absoliuti. Asmuo yra savęs paties, savo kūno ir sielos valdovas."

(Mill, 1995, 27-28).

Šie liberalizmo nuostatai atsispindèjo ir BJ, o vèliau ir modernioje alkoholio draudimo politikoje (Rasmussen, Benson, 2002). Bendruomenès gerovè ir laisvès apsauga buvo sujungti demokratinèje sistemoje, kuri nustatė aktyvų piliečių vaidmenị.

Atrodo, kad tokia ideologija, kuri pirmenybę teikè bendruomenès, kaip darnios visumos vertei, prieštarauja asmens laisvès idejoms ar bet kokiai vertybių sistemai, kurioje akcentuojamas individas. Vis dèlto, laikantis blaivybès minties, abu šie prieštaringi įsitikinimai buvo ịtraukti i platesnes mintis apie valstybės prigimtį. Blaivybės aktyvistai alkoholị ir jo pardavimus vertino kaip grèsmę tiek bendruomenei, tiek laisvei (Coombs, 2011). Blaivybès šalininkai argumentavo, kad negeriantis žmogus turi daugiau laisvès nei geriantis. Jų nuomone, alkoholis buvo ne tik nuodas, kuris sugadina žmogaus kūną, bet ir pavojinga medžiaga, pavergianti vyrus jų aistroms ir priverčianti atsisakyti aukštesnių protinių funkcijų. Tokių protinių sugebejjimų praradimas būtinai kenks žmogaus laisvei. Buvo reikalaujama susilaikyti nuo girtavimo, kad blaivybė suteiktų individui daug didesnę laisvę (Coombs, 2011). Alkoholis kaip kliūtis progresui buvo matomas tarptautinèse komunikavimo platformose, kuriose mokslininkai, blaivybès judèjimo aktyvistai bei politikai dalyvavo bendrose diskusijose, dalijosi praktinėmis patirtimis (Edman, 2015), vertė literatūrą ị savo kalbas (Smelova, 2021).

Remdamiesi idejja, kad verslas turètų prisidèti prie bendro gẻrio, daugelis draudimų šalininkų pasisakė už tai, kad vyriausybe turètų uždrausti bet kokią visuomenei žalingą komercinę veiklą. Norintiems dalyvauti alkoholinių gèrimų prekyboje reikejjo įrodyti, kad jų verslas bendruomenei bus labiau naudingas nei žalingas. Be paties alkoholio korupcinès galios, alkoholio pramonè buvo pavaizduota kaip grèsmè atskirų piliečių laisvei, ypač kai ji stengèsi paveikti politines partijas (Coombs, 2011). Kita vertus, BJ finansavo kitų nei alkoholio šakų pramonès atstovai (Wagner, 1987). Galima numanyti, kad to meto politinis ir socialinis laukas buvo kartu ir idejjinis mūšio laukas, kuriame blaivybès idejos labiau derèjo su to meto socialinès tvarkos, saugumo ir reprodukciniais interesais nei su išimtinai finansiniu ar ekonominiu valstybės interesu.

\section{BJ ir juos palaikančios interesų grupès}

Alkoholio žalos tyrimai ir jų sklaida turèjo įtaką visuomenès sąmonès kèlimui, blaivybès judejjimams bei politiniam atsakui ị problemą. $1804 \mathrm{~m}$. abiejose Atlanto pusèse, JAV ir Airijoje, du medikai publikavo po knygą, skirtą alkoholio klausimams (Trotter ir Porter „Medicinos, Filosofijos ir Chemijos esė apie girtumą ir jo poveiki žmogaus kūnui“ bei Ruch „Ardento spirito poveikio 
žmogaus kūnui ir mintims tyrinèjimas“) (Trotter ir Porter, 1988; Rush, 1816). 1818 m. J. Šimkevičiaus „Veikalas apie blaivybę“ puikiai įsiliejo ị to meto mokslinių žinių pasaulį, kartu net pateikè pasiūlymus, kaip spręsti girtuoklystès problemas ir rūpintis gerove (Aleksandravičius, 1991). Šie ir panašaus pobūdžio darbai skatino susirūpinimą ir kèlè klausimą: ką daryti, kad pašalintume girtavimą kaip gerovès kliūtį? Kaip atsakymas $1808 \mathrm{~m}$. JAV, Niujorke, susikūrè pirmoji blaivybės draugija (Couling, 1862), $1826 \mathrm{~m}$. Bostone - Amerikos blaivybės draugija, o vèliau jų pavyzdžiu seke kitos šalys, ypač protestantiškos. Tačiau BJ buvo ryškūs katalikiškose Airijoje (1829 m.) ir Lietuvoje (1858 m.). BJ ịtraukè vis daugiau žmonių, kurie jungèsi ị draugijas, ieškojo alternatyvių būdų blaiviam gyvenimui. Kad užpildytų girtavimo sustabdymo vakuumą, blaivybès skleidejjai vietoj alkoholio siūlè kurti parkus, sporto aikštes, bibliotekas, muziejus, keliauti, rūpintis higiena, švietimu. Tai buvo fizinio ir dvasinio tobulinimosi alternatyvos smuklèms. Blaivybès draugijų narių statusas buvo susietas su savitvarda, dorybe, atsakingumu ir pagarba. Blaivybès judèjimų propaguotos idèjos buvo nukreiptos $\mathfrak{i}$ visuomenę, o iš politikų reikalauta prohibicijos, reikalingos blaivybei palaikyti. JAV, Kanada, Suomija ir Rusija ịvede prohibiciją, o Norvegija, Švedija, Islandija ir Naujoji Zelandija buvo labai arti prohibicijos (Room, 2004).

Alkoholio tyrinètojai protestantiškose šalyse BJ ir griežtos alkoholio politikos apraiškas aiškino protestantiška etika (Rouse, Unntthan, 1993). Protestantiška etika siejama su kapitalizmo dvasia ir industrializacijos plètra. Protestantiška etika skatina blaivius ir disciplinuotus, produktyvius darbuotojus. Protestantai tikejjo, kad visi, ne vien kunigai, pašaukti Dievo darbams. Tikèta, kad Dievas teikia malonių, kas reiškė ir norą būti moraliu. Klestējimas, įskaitant verslo sritị, buvo suvokiamas kaip Dievo palaiminimas. Girtuoklystè vienareikšmiškai buvo nedisciplinos, neproduktyvumo, nemoralumo, nuodèmès išraiška (Rouse, Unntthan, 1993). Vis dèlto blaivybès judèjimai katalikiškoje Airijoje ir Lietuvoje protestantiška etika negali būti paaiškinami. Blaivybę kaip atsaką i alkoholio žalą palaikè ir kitos krikščionybės šakos.

BJ ir jų kontekstų bei alkoholio politikos raidos tyrimo apžvalga atskleidžia ne tik pačių BJ svarbą, bet ir jų patrauklumą ịvairioms interesų grupèms. Čia galima paminèti tokius judejjimus, kaip išsilaisvinimo iš vergijos (Yacovone, 1988) ir baudžiavos (Aleksandravičius, 1991), moterų ir darbininkų teisių judejimus, socialistinès ir bolševikinès minties (Calhoun, 1993), tautinès, rasinès ir gerovès valstybès siekinius (Kamenov, 2020; Blocker, Fahey \& Tyrrell, 2003). Kiekviena interesų grupé turèjo ,prasmès sistemą, ittvirtintą veiksmų strategijoje“ (Healey, 1997), kurioje blaivi ir stipri bendruomenè, o vẻliau išsirutuliojusi tauta buvo prioritetinis dalykas.

Moteru blaivybès ir teisių judèjimai. Moterų judèjimuose blaivybė buvo patraukli idèja, nes ja buvo siekiama nutraukti reiškinį, kuris tiesiogiai paveikè daugelio moterų gyvenimo kokybę. Moterys šiuose judejjimuose buvo vyrų girtavimo aukos bei aktyvios veikèjos, nuo kurių atsakomybès priklausė blaivybės ir bendrai šeimos, o kartu ir valstybės gerovè. Blaivybè buvo religinè ir moralinė pareiga, puikiai deranti su kitomis moteriškomis pareigomis. Buvo manoma, jei būtų pasiekta visiška abstinencija, šeima, jos namai, sveikata ir net išganymas būtų apsaugoti. Moterų krikščioniškoji blaivybès sajunga buvo pirmoji nacionalinè organizacija, ikurta $1874 \mathrm{~m}$. Ši organizacija pateikè politinio įsitraukimo modeli, kuris svarbus ne tik blaivybès, bet ir balsavimo ir kitų moterų teisių reikalavimo aspektais. Pirmos bangos feminisčių judèjimas išaugo iš krikščionių moterų BJ (McPhillips, 2016; Tyrrell, 2014). Moterys Prancūzijoje, Vokietijoje, Didžiojoje Britanijoje, JAV ir kitose industrinèse šalyse sukūre pagrindines organizacijas, nacionalines ir tarptautines lobistines grupes, siekdamos palaikyti motinos ir vaiko gerovę. Daugelị jų sukurtų programų vèliau perèmé šios srities viešosios politikos (Koven, Michel, 1990), o subsidiarinès gerovès valstybès periodu jos sèkmingai bendradarbiavo su valstybe suvienydamos pastangas siekti bendro tikslo - gerovès (Lucas, 2004).

Moterų teisių judejjimai ir moterų BJ sudarè koalicijas, naudingas tiek moterų teisių siekimui, tiek prohibicijai, tiek gerovès sistemos kūrimui paremti (McCammon, Campbell, 2002; Tyrrell, 2014). Reikia pridurti, kad Rusijoje ir Lietuvoje moterys savarankiškų blaivybės draugijų nebuvo įkūrusios, tačiau prisidèjo prie BJ išreikšdamos savo susirūpinimą ir palaikymą, o pastarasis buvo itin susijęs su moterų teisių klausimu (Smelova, 2021; Kačerauskas, 2013; Ogawa, 2007). 
Darbininku, socialistu ir juos palaikančiuju judëjimai. Darbininkai, socialistai, kairieji reikalavo blaivybės tiek siekiant asmeninio tobulejjimo, vyriškumo ir pagarbos, tiek siekiant priešintis priespaudai darbe ir kovoti už darbininkų teises. Garsiausias iš šių judejjimų buvo 1840-ųjų pradžios Vašingtono blaivybės judejjimas (Taillon, 2002). Socialistai siekè patraukti kuo daugiau darbininkų (Kamenov, 2020). Tuo metu socialistai kèlè klausimą: kodėl žmonès geria? Bandè susieti šį reiškinị su gyvenimo ir darbo sąlygų klausimu, skurdu. Jų diskursas pakeite priežastini ryši ir nustate piktnaudžiavimo alkoholiu priežastị blogose socialinėse darbininkų klasės sąlygose (Lucas, 2004). Bene didžiausias skirtumas nuo protestantiškų šalių, kuriose BJ buvo itin gajūs, j̨žvelgiamas Imperinèje Rusijoje, ypač bolševikams paėmus valdžią i savo rankas. Caro prohibicijos įvedimas 1914 m. siejamas su interesu turèti blaivią, stiprią, susikoncentravusią kariuomenę (Herlihy, 2017). Imperinès Rusijos, o vèliau ir TSRS, prohibicija aiškinama per proletarinę etiką, kuri siejama su socialistiniu kvietimu tikèti beklasès visuomenès pranašumu, kuriam pasiekti būtina socialistinė revoliucija. Pokyčiams reikèjo „teisingos“ socialistinès sąmonės, kuri buvo bolševikų tikslas. Tinkama sąmonė reiškè pritarti mokslinio socializmo teorijoms. Per tokį visuomenès transformavimą $\mathfrak{i}$,šviesesnị“ rytojų buvo kviečiami visi aktyvistai valstybèje, įskaitant darbininkus. Leninas akcentavo darbo našumą, drausmę, skelbè kultūrinị karą niekšybei, nerūpestingumui, netvarkingumui, nepunktualumui, nervingam skubejjimui. Tarnavimas partijai sunkiu darbu ir sąmoningumu buvo proletarinès etikos šerdis, susijusi su darbo šventumu ir grupès poreikių pirmumu prieš individualius norus (Rouse, Unntthan, 1993). Tinkamos socialistinès sąmonès formavimas bus negailestingas kitaip mąstantiems, kurių patirtas košmariškas kančias atskleidė Solženicynas „Gulago archipelage“ (Solženicynas, 2009). Skelbiant proletarinę ideologiją buvo kovojama su alkoholiu kaip trukdžiu ugdyti proletarinę sąmonę. Tuo galima paaiškinti, jog perėmę valdžią bolševikai neatšaukè alkoholio prohibicijos iki 1925 m., nepaisant karinių išlaidų ir bado. Pats darbininkų ir valstiečių girtavimo mažinimas nebuvo tikslas savaime, tačiau rimta priemonè proletarinès sąmonès ugdymui (Rouse, Unntthan, 1993). Marksas ir daugybė aktyvistų pasiūlè teiginį, kad bendra darbuotojo tapatybė turètų būti svarbesnè už amatų, regiono, etninès ir kitos tapatybès ịvairovę (Calhoun, 1993:395). Rusijoje vyravusi proletariškos etikos dvasia labai skyrėsi nuo protestantiškos, tačiau abi visuomenès panašiai apibūdina ir reaguoja ị su alkoholiu susijusias problemas: alkoholikai politinèjeekonominèje sistemoje apibrěžiami kaip neproduktyvūs, todèl, siekiant produktyvumo, alkoholị reikia drausti.

Kalbant apie darbininkų blaivybę, reikètų pabrežti, kad ją palaikė ir darbdaviai, kuriems reikèjo blaivių darbuotojų sparčiai besiplečiančiai ir technologizuojamai pramonei. Verslo elitas matė blaivybę kaip pelningą ir naudingą darbo jègos kontroliavimo priemonę, ypač mažinti smurtui streikų metu. Alkoholio kontrolè buvo siejama ir su tvarkos bei saugumo interesu. Pritarimas prohibicijai ar bent jau labai griežtam licencijavimui buvo juntamas ir dèl ịstatymu ịtvirtintų kompensacijų už nelaimingus atsitikimus darbe. Vis dèlto ị girtavimą buvo žiūrima kaip ị ,valingą blogą elgesįi“, už kurị atsakomybė teko pačiam darbininkui (Wagner, 1987).

Sveikatos draudimo bendrovès taip pat buvo blaivybès šalininkès, stengèsi apdrausti tik blaivininkus. Pavyzdžiui, Ansvar grupè Švedijoje tikèjo, kad jų verslas gali duoti pridètinę vertę, skatinti geresnę visuomenę, kuri remtųsi abstinencija ir krikščionišku gyvenimo būdu. Švedijoje blaivybès draugijos palaikè ir inicijavo sveikatos draudimą, o $1909 \mathrm{~m}$. šalyje buvo 116 draudimo bendrovès, kurios nedraudè stipriai geriančių asmenų. JK ir JAV BJ skatino blaivybei draugišką visuomenę, blaivybės draudimo kompanijas, o rizikos grupes - totaliai abstinencijai (Bergquist, Eriksson, 2019).

Tautinès valstybès kūrimo ir stiprinimo judëjimai. Tautinès valstybès kūrimo ir stiprinimo diskursas buvo glaudžiai susijęs su blaivybės siekimu, nes buvo rūpinamasi, kad moderni visuomenė nedegraduotų. BJ periodu, ypač XX a. pradžioje degradacijos baimé buvo labai stipri. Stipriai tautinei valstybei reikèjo stiprios ir sveikos tautos. Buvo manoma, kad apsišvietusi tautinè valstybė, persmelkta siekio ir atsidavimo moralinei ir socialinei pažangai, yra išorinè priemonè kurti vidinị piliečiu , aš“, gebanti susivaldyti ir kompetentinga veikti kaip suvereni narè (Sulkunen, Warpenius, 2000). Ateities kartos buvo raktinė problema, pateikinejjama platesniame kontekste. Buvo susirūpinta, 
kad žmonija silpsta dèl alkoholio vartojimo, nes esamos kartos nuodėmė mažina būsimos kartos šansus. Bendrai buvo sutariama ir siekiama gyventojų kokybės ir ateities kartu gerovès, efektyvios infrastruktūros, pramonès konkurencingumo, stiprios karinès institucijos, pilietiškumo sampratos, valstybès stiprybės ir atsakingo vaidmens. Tautos, turinčios tokius tikslus ir norinčios matyti blaivius ir stiprius piliečius, pažangios blaivybès judèjimo jègos buvo skatinamos imtis daugybès klausimų (Edman, 2015).

Nors BJ fenomenas dažnai aiškinamas protestantiška ir proletariška etika, tačiau Airijos ir Lietuvos atvejai yra išimtys. Th. Mathew Airijoje 1843 metais ị blaivybès judejjimą ịtraukè 6 milijonus blaivybès priesaiką pasirašiusių, kurie prisiekė Dievo akivaizdoje būti abstinentai, nesiūlyti alkoholio bei skleisti blaivybès idèjas. Blaivybès idèja socialiniais ir politiniais tikslais vèliau buvo sutelkta aplink „tautos“ kategoriją (Beckingham, 2014). Analogiškas vaidmuo tenka Motiejaus Valančiaus judèjimui Lietuvoje. Rusijos imperijos taikyta proletariška etika, rusifikacija Lietuvoje buvo atremta ir šiame procese vienas esminių vaidmenų tenka blaivybės judejjimams, siejamiems su lietuviškos kalbos išlaikymu ir tautinès sąmonès stiprinimu (Aleksandravičius, 1991; Merkys, 1999: Kačerauskas, 2013). Su tuo galima sieti ir alkoholio vartojimo rezultatą: XIX a. pabaigoje Rusijos Imperijoje vidutiniškai vienam gyventojui Kostromos mieste teko 17,9 litrų suvartoto gryno alkoholio (tik iš degtinès), Maskvoje - 9,4, o Kaune - 3,4 litro (Blocker, Fahey, Tyrrell, 2003:15) ir savarankiškos nepriklausomos Lietuvos valstybès sukūrimą, išsaugant tautos identitetą.

XIX a. pabaigoje ir XX a. pradžioje daugelyje šalių tautinè tapatybe turèjo viršenybę prieš klasę, regioną, tarmę, lytị ir kitas pagalbines tapatybes (Calhoun, 1993). Bijantis tautos degeneracijos, buvo renkamasi tautos stiprinimo strategijos, pvz., švietimo, sveikatos, o kraštutiniais atvejais ir žiaurios intervencinès strategijos, sietinos su eugenikos ir nacizmo judejjimais ir politikomis.

Higienizmas įtraukè infekcinių ligų prevenciją, sveiką mitybą, vegetarizmą, siekè kelti gyvenimo kokybę, blaivybės idejjos jam buvo palankios (Edman, 2015). Eugenikos judèjimas nuo pat pradžių atkreipè dèmesị į neblaivios tẻvystès klausimą (Saleeby, 1910). Pirmieji keturi dvidešimtojo amžiaus dešimtmečiai būdingi agresyviam biologinių argumentų taikymui visuomenèje: atèjo laikas eugenikai ir jos planui politiškai ir valdingai ịsikišti ị intymiausią žmogaus prigimties branduolị, vykdyti genetinès ateities kontrolę dirbtinès atrankos būdu. $1907 \mathrm{~m}$. pirmasis sterilizavimo įstatymas priimtas JAV, Indianoje, nuo $1928 \mathrm{~m}$. Šveicarijoje, Skandinavijos šalyse, Vokietijoje. Eugenika buvo susieta su tautų pažanga, lenktyniavimu, konkurencija ir turèjo pasiūlyti greitesnę atrankos sistemą nei gamta (Meloni, 2016). Rasistinejje Vokietijoje žmonių sterilizavimas, kaip ir žudymas, gryninant rasę skyrèsi nuo kitų šalių higienizmo (Roberts, 2019). Vokietijoje asmenys, kurių alkoholio vartojimas kèlè nerimą, tačiau biologinis paveldas buvo vertas dèmesio, buvo laikomi išgydomais ir gydomi. Sunkus alkoholizmas buvo suvokiamas kaip paveldima arba biologinė grèsmè, kurią reikèjo gydyti biologiškai, t.y. sterilizuoti (Lewy, 2009), o tokius asmenis siųsti ị darbo stovyklas (EisenbachStangl, 2004).

Nors alkoholio žala blaivybės judejjimų ir jų rẻmėjų buvo suvokiama labai plačiai, tačiau prohibicijos reikalavimas ir tikejjimas, kad ji išspręs visas socialines ir ekonomines problemas, buvo utopinis. Šị utopinị požiūrị atskleidžia evangelisto Billy Sunday pamokslo, sakyto prohibicijos ịvedimo proga tūkstantinei miniai fragmentas: „Ašaru karalystè baigèsi. Lūšnynai netrukus bus prisiminimas. Savo kalèjimus paversime gamyklomis, o areštines - sandèliais ir kukurūzu lopšiais. Vyrai dabar vaikščios išsitiesę, moterys šypsosis, o vaikai juoksis“ (Levine, Reinarman, 1991, 463 p.). Kad tai utopija, atskleidè vèlesnè istorinè patirtis. Galima daryti prielaidą, kad nusivylimas utopija prisidejo prie blaivybès judejjimų nutildymo, o kartu ir alkoholio politikoje issivyravusių fiskalinio ir ekonominio interesų.

\section{Išvados}

1. Nors modernūs BJ gimè iš moralinio reguliavimo, kur girtavimas buvo nuodèmè, o blaivybė - dorybė, tačiau masinę išraišką igavo tik suvokus alkoholio žalą geriančio ,mintims ir kūnui“, šeimai, saugumui, bendruomenei, produktyvumui ir tautai. Moralinio reguliavimo modelis nesikirto su klasikinio liberalizmo mintimi, kur žala kitiems buvo matoma kaip pateisinama 
intervencija ribojant individo laisves. Alkoholio žalos holistinis suvokimas orientavo BJ ir juos palaikančias jègas reikalauti blaivybę palaikančios politikos - prohibicijos, kuri fiskalinị ir ekonominị alkoholio interesą nustūmė ị paraštes. Nors žala buvo suvokiama holistiškai, tačiau prohibicionistinis problemos sprendimas buvo vienpusiškas, utopinis.

2. Prohibicionistai kritikavo lasser-faire politiką, reikalavo valstybès atsakomybès ginant individų laisves. BJ ir prohibicijos reikalavimą palaike ịvairios visuomenès grupès: moterys, darbininkai, valstiečiai, vidurinė klasė (buržuazija), politikai, ypač socialistai, bolševikai, nacionalistai, nacistai. Šioms grupèms blaivybẻ buvo priimtina priemonè siekti kolektyvinių tikslų, susietų su viešaja tvarka, saugumu, prokreacija, tautos stiprinimu ir progresu. Priklausomai nuo kultūros, BJ pasiekè nevienodą viešosios politikos atsaką i problemą. Atsaką galima apibendrinti kaip prohibiciją, alkoholio kontrolę bei dalinị ar visišką alkoholio monopolị.

3. BJ buvo glaudžiai susiję su juose dalyvavusių ir juos palaikiusių grupių naujaja tapatybe, gyvenimo būdu, kova už žmogaus teises, gerovès bei naujos politikos siekimu. BJ įrèmino holistinį alkoholio žalos suvokimą, išryškino blaivybės teikiamą naudą ịvairioms interesų grupėms, kas ịgalino griežtos alkoholio politikos palaikymą. Šie veiksniai išlieka aktualūs ir šiandien, siekiant veiksmingos alkoholio žalos prevencijos bei nuo žalos kenčiančiųjų teisių apsaugos.

\section{Pastabos}

Šis straipsnis parengtas ịgyvendinant Lietuvos mokslo tarybos finansuojamą projektą Nr. SMIP-20-2 „Irodymais grịstos alkoholio politikos vystymas remiantis standartizuotu Europos alkoholio tyrimu: Lietuvos atvejis“" (DAP SEAS LT).

\section{Literatūra}

1. Aleksandravičius, E. (1991). Blaivybe Lietuvoje XIX amžiuje. Sietynas.

2. Beckingham, D. (2014). The press and the pledge: Father Theobald Mathew's 1843 temperance tour of Britain. Historical Geography, 42, 93-110.

3. Bergquist, A. K., \& Eriksson, L. (2019). Sober business: Shared value creation between the insurance industry and the temperance movement. Business History, 61(2), 322-342.

4. Berridge V, 2005, Temperance: its history and impact on current and future alcohol policy, Drugs and Alcohol Research Programme, Joseph Rowntree Foundation, York

5. Blocker, J. S., Fahey, D. M., \& Tyrrell, I. R. (2003). Alcohol and temperance in modern history: an international encyclopedia (Vol. 1). ABC-CLIO.

6. Butler, E. (2015). Classical Liberalism-A Primer. London Publishing Partnership.

7. Calhoun, C. (1994). "New Social Movements" of the Early Nineteenth Century". Social Science History, 17(3), 386-427.

8. Cockx, L., Meloni, G., \& Swinnen, J. (2019). The water of life and death: a brief economic history of spirits (No. 41719). LICOS-Centre for Institutions and Economic Performance, KU Leuven. https://www.researchgate.net/publication/337059592_The_Water_of_Life_and_Death_A_Brief_Economic_Histor y_of_Spirits.

9. Collins, J. A., \& Fauser, B. C. (2005). Balancing the strengths of systematic and narrative reviews. Human Reproduction Update, 11 (2), 103-104.

10. Coombs, A. J. (2011). Liberty and Community: The Political Ideas of Nineteenth-Century Canadian Temperance Movements. The Graduate History Review, 3(1).

11. Couling, S. (1862). History of the Temperance Movement in Great Britain and Ireland. W. Tweedie. https://scholar.google.com/scholar?hl=en\&as_sdt=0\%2C5\&q=Couling\%2C+S.+\%281862\%29.+History+of+the+ Temperance+Movement+in+Great+Britain+and+Ireland.+W.+Tweedie.\&btnG=

12. Edman, J. (2015). Temperance and modernity: Alcohol consumption as a collective problem, 1885-1913. Journal of social history, 49(1), 20-52.

13. Eisenbach-Stangl, I. (2004). From Temperence Movements to State Action: An Historical View of the Alcohol Question in Industrialised Countries. In From Science to Action? 100 Years Later-Alcohol Policies Revisited (pp. 59-69). Springer, Dordrecht.

14. Ferrari, R. (2015). Writing narrative style literature reviews. Medical Writing, 24(4), 230-235.

15. Flor, L. S., \& Gakidou, E. (2020). The burden of alcohol use: better data and strong policies towards a sustainable development. The Lancet Public Health, 5(1), e10-e11.

16. Fogarty, D. (1985) From saloon to supermarket: packaged beer and the reshaping of the U.S. brewing industry, Contemporary Drug Problems 12:541-592. 
17. Gaus, Gerald F. (1983). Public and Private Interests in Liberal Political Economy, Old and New, in Public and Private in Social Life, S.I. Benn and G.F. Gaus (eds.), New York: St. Martin's Press: 183-221.

18. Healey P. 1997. Collaborative Planning: Shaping Places in Fragmented Societies,Basingstoke: Macmillan

19. Herlihy, P. (2003). The alcoholic empire: vodka \& politics in late Imperial Russia. Oxford University Press on Demand.

20. Herlihy, P. (2017). The Russian Vodka Prohibition of 1914 and Its Consequences. In Dual Markets (pp. 193-206). Springer, Cham.

21. Yacovone, D. (1988). The Transformation of the Black Temperance Movement, 1827-1854: An Interpretation. Journal of the Early Republic, 8(3), 281-297. doi:10.2307/3123691

22. Yeomans, H. (2011). What did the British temperance movement accomplish? Attitudes to alcohol, the law and moral regulation. Sociology, 45(1), 38-53

23. Kačerauskas, J. (2013). Blaivybe Lietuvoje: istorija ir dabartis. Diemedžio leidykla.

24. Kamenov, N. (2020). A Global Imaginaire: Fighting Alcohol around the World. In Global Temperance and the Balkans (pp. 19-58). Palgrave Macmillan, Cham.

25. Koven, S., \& Michel, S. (1990). Womanly duties: Maternalist politics and the origins of welfare states in France, Germany, Great Britain, and the United States, 1880-1920. The American historical review, 95(4), 1076-1108.

26. Laslett, A. M., Callinan, S., \& Pennay, A. (2013). The increasing significance of alcohol's harm to others research. Drugs and Alcohol Today, 13(3), 163-172..

27. Lee, S. L. (2020). The Effects of Temperance Club Activities on Drinking, Health, and Food Habits of College Student. Journal of Korean Home Economics Education Association, 32(3), 49-61.

28. Levine, H. G. (1984). The alcohol problem in America: From temperance to alcoholism. British Journal of Addiction, 79(4), 109-119.

29. Levine, H. G. (1992). Temperance cultures. Lader et. E. Edwards (Eds.) The nature of alcohol and drug related problems, 16-36.

30. Levine, H. G., \& Reinarman, C. (1991). From prohibition to regulation: lessons from alcohol policy for drug policy. The Milbank Quarterly, 461-494. P.463

31. Lewy, J. (2009). A biological threat or a social disease? Alcoholism and drug addiction in Nazi Germany. Journal of European Studies, 39(3), 371-385.

32. Lietuvos alkoholio bendrovès https://lt.wikipedia.org/wiki/Kategorija:Lietuvos_alkoholini\%C5\%B3_g\% C4\%97rim\%C5\%B3_bendrov\%C4\%97s

33. Lucas, B. (2004). Reducing Discursive Complexity: The Case of Alcohol Policies in Europe (1850-2000). In From Science to Action? 100 Years Later-Alcohol Policies Revisited (pp. 71-100). Springer, Dordrecht.

34. Mäkelä, K., \& Viikari, M. (1977). Notes on alcohol and the state. Acta Sociologica, 20(2), 155-179.

35. McCammon, H., \& Campbell, K. (2002). Allies on the road to victory: Coalition formation between the suffragists and the Woman's Christian Temperance Union. Mobilization: An International Quarterly, 7(3), 231-251.

36. McCloskey, D. N. (2010).Bourgeois dignity: Why economics can't explain the modern world. University of Chicago Press.

37. McPhillips, K. (2016). Contested Feminisms: Women's Religious Leadership and the Politics of Contemporary Western Feminism. Journal for the Academic Study of Religion, 29(2).

38. Meloni, M. (2016). Political biology: Science and social values in human heredity from eugenics to epigenetics. Springer

39. Merkys, V. (1999). Motiejus Valančius: tarp katalikiškojo universalizmo ir tautiškumo. Vilnius: Mintis.

40. Mill, J. S. (1995). Apie laisvę. Vilnius: Pradai.

41. Moskalewicz, J., Room, R., \& Thom, B. (2016). Comparative monitoring of alcohol epidemiology across the EU. Baseline assessment and suggestions for future action. Synthesis report. Warsaw: RARHA.

42. Ogawa, M. (2007). The "White Ribbon League of Nations" Meets Japan: The Trans-Pacific Activism of the Woman's Christian Temperance Union, 1906-1930. Diplomatic History, 31(1), 21-50.

43. Örnberg, J. C. (2008). The Europeanization of Swedish alcohol policy: the case of ECAS. Journal of European Social Policy, 18(4), 380-392.

44. Porter, R. (1985). The Drinking Man's Disease: The 'Pre-History'of Alcoholism in Georgian Britain. British Journal of Addiction, 80(4), 385-396.

45. Rasmussen, D. W., \& Benson, B. L. (2002). Rationalizing drug policy under federalism. Florida State University Law Review., 30, 679-734, p.687.

46. Roberts, J. S. (2019). (Drink, temperance and the working class in nineteenth century Germany. New York: Routledge.

47. Room, R. (1997). Alcohol, the individual and society: what history teaches us. Addiction, 92, S7-S11

48. Room, R. (1999). The idea of alcohol policy. Nordic Studies on Alcohol and Drugs, 16(1_suppl), 7-20.

49. Room, R. (2004). Alcohol and harm reduction, then and now. Critical Public Health, 14(4), 329-344.

50. Room, R., Ferris, J., Laslett, A. M., Livingston, M., Mugavin, J., \& Wilkinson, C. (2010). The drinker's effect on the social environment: a conceptual framework for studying alcohol's harm to others. International journal of environmental research and public health, 7(4), 1855-1871. 
51. Rouse, T. P., \& Unntthan, N. P. (1993). Comparative ideologies and alcoholism: The protestant and proletarian ethics. Social Problems, 40(2), 213-227.

52. Saleeby, C. W. (1910). Racial poisons, II alcohol. The Eugenics Review, 2(1), 30.

53. Sandberg, S. (2006). Fighting neo-liberalism with neo-liberal discourse: ATTAC Norway, Foucault and collective action framing. Social Movement Studies, 5(3), 209-227.

54. Smelova, A. (2021). Between the Nation and the Empire: The Transmission of Texts and Ideas about Temperance in the USA and Russia in the early 20th century. Global Histories: A Student Journal, 6(2).

55. Solženicynas, A. (2009). Gulago archipelagas 1918-1956: literatūrinè studija, 1. tomas (iš rusų k. vertė Viktoras Beržinis). Vilnius: Țara.

56. Sulkunen, P. (1987). Alcohol policies fin de siècle. Health Policy, 7(3), 325-338.

57. Sulkunen, P., \& Warpenius, K. (2000). Reforming the self and the other: the temperance movement and the duality of modern subjectivity. Critical Public Health, 10(4), 423-438.

58. Taillon, P. M. (2002). "What we want is good, sober men:" masculinity, respectability, and temperance in the railroad brotherhoods, C. 1870-1910. Journal of Social History, 36(2), 319-338.

59. Tamutienè, I., \& Graužinè, M. (2013). Alkoholio kontrolès politikos tikslo apibrèžties ir mažmeninès prekybos licencijavimo problematika Lietuvoje. Viešoji politika ir administravimas, 12(3), 483-497.

60. Tamutienè, I., Andrejeva, R., \& Lazauskienè, A. (2016). Prekybos alkoholiu vietų reguliavimas: Pirmosios ir Antrosios Lietuvos Respublikos patirtys. Viešoji Politika ir Administravimas, 15(1),25-40.

61. Tyrrell, I. (2014). Woman's world/Woman's empire: the Woman's Christian Temperance Union in international perspective, 1880-1930. UNC Press Books.

62. Wagner, D. (1987). The new temperance movement and social control at the workplace. Contemporary. Drug Problems, 14, 539-556. P. 547-548

\section{Ilona Tamutienè}

\section{The Influence of the Perception of Alcohol's Harm on the Support of Temperance Movements in the Nineteenth and Early Twentieth Centuries}

\section{Abstract}

The purpose of this article is to reveal the role of the perception of alcohol's harm in the outcomes of Temperance Movements (TM) and of the different interest groups that supported them. The tasks to achieve this goal are the following: 1) to describe the interests of alcohol policy; 2) to reveal how the harm of alcohol was seen in the context of classical liberalism; 3 ) to identify how the harm of alcohol was positioned by TM; 4) to outline the interest groups that supported TM and the political response to it. The article is based on the review and interpretation of literature. Social movements and different interest groups saw the harm of alcohol holistically during the period of Temperance hegemony (19th and 20th centuries): starting with the drinker but emphasizing the community interest. Classical liberalism considered the harm alcohol caused to other people, not the drinker himself, as a reasonable principle to restrict the drinker's freedom. Temperance in the context of moral regulations was a virtue and a feature of higher status with regard to the person's dignity, value, productivity, health and education. Social movements that promoted and supported temperance allowed to choose between two extremities: i.e., one leading to degradation and the other to prosperity. TM members took a pledge to abstain from alcohol, to encourage others to be sober and to promote sobriety. There were several interest groups alongside TM that supported this movement: the women who sought welfare of the family and country and protection of their own rights; workers who sought their rights; capitalists who needed sober workers; socialists who needed the votes of the workers; the Bolsheviks, who needed sober workers to cultivate proletarian consciousness. Sobriety was a means to develop a national consciousness and create a sovereign state that promoted liberation and health. Temperance was supported by the movements of eugenics, hygiene and race purification. TM showed sober life to be the means of achieving higher goals through individual and collective action. A strict alcohol policy, which ranged from strict licensing to total prohibition, was required to achieve a sobriety-friendly environment. 
Ilona Tamutiene, professor, Department of Public Administration, Vytautas Magnus University, Lithuania.

E-mail: ilona.tamutiene@vdu.lt

Ilona Tamutienè, profesorè, Viešojo administravimo katedra, Vytauto Didžiojo universitetas, Lietuva El. paštas: $\underline{\text { ilona.tamutiene@ vdu.lt }}$ 